LiNGUACULTURE

\title{
A DIACHRONIC PERSPECTIVE ON THE ENGLISH PREPOSITION TO AND THE ROMANIAN PREPOSITION LA
}

\author{
Tania ZAMFIR \\ Transilvania University of Brașov
}

\begin{abstract}
The paper discusses the different evolution of the English preposition (P) to and the Romanian P la "at/to" which can be observed in the history of English and Romanian ditransitives. In Modern English (ModE), the preposition to can occur in configurations with (i) ditransitive predicates and (b) unaccusative predicates. Within ditransitives, the English to only functions in the prepositional frame and it has a narrow distribution; the to-dative is a genuine Goal or a Recipient with certain verb classes. The first focus of this paper is to investigate the presence of the to-dative in Old English (OldE). The investigation will reveal that the to-dative construction was neither rare nor restricted, but already present in OldE. By way of contrast, Romanian la has a richer distribution (Possessor Goal, Beneficiary, Maleficiary and Source) and it has shifted from a case marker to a [Person] marker and it has moved in the direction of inflectional dative. The second focus of the paper is to investigate the presence of la in OldR. I will show that Romanian la evolved from the Latin $\mathrm{P} a d$; diachronically, Romanian has kept the analytical marking of the Dative which is realized through the P la "at/to".
\end{abstract}

Keywords: ditransitives, to-dative, la-dative, Old English, Old Romanian

\section{INTRODUCTION}

In this paper I turn to a diachronic perspective on the English $\mathrm{P}$ to and the Romanian P $l a$ and I will show that the two (functional) prepositions evolved differently. Specifically, the paper investigates the OldE roots of to-datives in ditransitive constructions and OldR roots of la-datives in ditransitive 
constructions. In order to understand the evolution from OldR to ModR it is incumbent on us to briefly introduce and comment on the behavior of to in ModE and la in ModR.

I will start from the observation that English exhibits a Dative alternation between two syntactic patterns, the Double Object Construction (DOC) and the Prepositional Dative Construction (PDC), where the latter is marked by the preposition to (see (1a,b) below).

(1) a. Double object construction (DOC)

She bought the children a puppy.

b. Prepositional Dative construction (PDC)

She bought a puppy to the children.

As shown in (1) above, for the DOC the Goal and the Theme are NPs which appear in the order V-Goal-Theme. For the PDC the Goal is an NP which follows the Theme where the order is V-Theme-Goal. In other words, the Dative alternation amounts to (i) the loss of the $\mathrm{P}$ to and (ii) the change of word order. Thus, to has become a redundant $\mathrm{P}$ because it can be deleted.

Within the verbal domain, to can occur in configurations with (a) ditransitive predicates and (b) unaccusative predicates. Within ditransitives, to encodes a Goal interpretation, which is predictable from the structure of the verb; the to-dative is a genuine Goal when realized by throw-type verbs and their subclasses and a Recipient with give-type verbs (see $(2 \mathrm{a}, \mathrm{b})$ below).

(2) a. John threw the ball to Tom. (Goal)

b. John gave the gift to Pauline. (Recipient)

With give-type verbs, to cannot be associated with a Goal interpretation, because give-type verbs, as compared to send/throw-type verbs lose their Path component and cannot have a change of location reading (cf. Rappaport Hovav and Levin, 2008). Give-type verbs have only a transfer of possession interpretation. Irrespective of the presence/absence of the $\mathrm{P}$ to, the argument structure of "give" is <Agent, Recipient, Theme $>$. As a result, to is a functional $\mathrm{P}$, a case marker. Furthermore, English, unlike Romance languages, distinguishes between Goal and Location ("go to"/ "be at") (see $(3 a, b)$ below); Romanian translates this pair into a single $\mathrm{P}: l a$ "at/to".

(3) a. John threw the ball to Mary. (Goal)

b. He's standing at the window. (Location)

Diachronically, the presence of the to-dative is first attested in OldE texts (cf. de Cuypere 2014) while the alternation between the two syntactic frames was attested as early as Middle English especially with transfer verbs (see section 2 for a description). 
Romanian has kept from Old Latin the analytical marking of the Dative, which is realized through the $\mathrm{P}$ la "at/to". For this reason, Romanian la has evolved differently. It has widened its thematic sphere and it is associated with Goal/ Possessor Goals (with verbs of giving and throwing), Beneficiaries (with a pregăti "prepare", a găti "cook", a coace "bake", etc.), Maleficiaries or Source (with a fura "steal", a răpi "abduct", a șterpeli "flitch" etc.) that are specific to the inflectional dative and which denote human individuals with an inherent [Person] feature (see (4a-c) below). It is important to mention that $l a$ has widened its thematic sphere, but it has become semantically bleached as its semantic content is predictable from the structure of the verb.

(4) a. (Le)-au dăruit cadouri bunicilor/ la bunici (Goal) They.CL.DAT-have given presents grandparents.THE.DAT/ at grandparents "They have given presents to the grandparents."

b. Bunicul le-a copt mere nepoților/la nepoți (Beneficiaries) Grandfather they.CL.DAT-has baked apples grandchildren.THE.DAT/ at grandchildren "Grandfather baked some apples for his grandchildren"

c. Niște hoți le-au furat bunicilor/ la bunici niște vinete din gradină (SOURCE) Some thieves they.CL.DAT-have stolen grandparents.THE.DAT/ at grandparents some eggplants from the garden

"Some thieves stole the grandparents some eggplants from the garden"

Romanian Dat can be marked both (i) inflectionally and (ii) prepositionally by the $\mathrm{P}$ la "at/to", as in (5) below.

(5) a. Le-au cumpărat jucării nepoților. they.CL.DAT have bought toys nephews.THE.DAT "They have bought toys to the nephews"

b. Le-au cumpărat jucării la nepoți. they.CL.DAT have bought toys to nephews "They have bought toys to the nephews"

Dative arguments introduced by the Romanian $l a$ are DPs when they can be doubled by the clitic and la is analyzed as (a) a functional P; when la phrases cannot be doubled by the clitic they will be interpreted as PPs and la as (b) a lexical $\mathrm{P}$. Clitics exhibit a lexical specification for [uPerson] where clitic doubling of the la-phrase brings about one special property of la - [Person] marker.

As opposed to the English P to, the role of $l a$ is that of a category shifter, for it shifts the PP into a KP, thus an extended DP. La ${ }^{\wedge}$ DPs can be analyzed as $\mathrm{KPs}$, with $\mathrm{K}$ as a Dat head, but they can still be analyzed as PPs with a Goal/Location interpretation (Cornilescu 2020). 
Diachronically, OldR texts indicate a high frequency of $l a$ as a prepositional marking of the Dative, which led to its standardization as a Dat marker in the $17^{\text {th }}$ century (see section 3 for a description).

I may now turn to the investigation of to-dative in OldE.

\section{A DIACHRONIC PERSPECTIVE ON TO}

The presence of the to-dative construction in OldE was neither rare, nor restricted, but already present in the language. Leaning on de Cuypere (2014) the to-dative was commonly used in OE texts, contrary to what has been argued in the literature so far. De Cuypere (op. cit.) argues that OldE exhibited the same ordering tendencies of the dative as in present-day English, where both the NPto-PP and to-PP-NP were considered grammatical, with the NP-to-PP being the most frequent syntactic structures (2). The choice between the two syntactic patterns seems to have been influenced by several factors such as pronominality of the Acc and to-dative, Definiteness of the Acc, Number of Dat and Length between Acc/to-dat (36).

The to-dative construction was first attested in OldE with certain classes of ditransitive verbs such as verbs of communication (e.g. cweðan "to say", sprecan "to speak", witegian "to prophecy") or verbs of caused motion (e.g. sendan "to send", bringan " to bring") as shown in ((60a-d) cf. de Cuypere $(6-7,28))$; furthermore, the literature (Cassidy 1938) notes that with these classes of verbs, the to-construction was more frequent than the DOC.

(6) a. God cwæð to Moysen ðæt he wolde cumin.

"God said to Moses that he would come"e

b. and he hine sona to pære abbudissan gelædde. "and he immediately led him to the abbess"

c. and his halgan Fæder be hine asende to us and his holy father who him sent-out to us "and his holy father, who sent him out to use

At a closer look, to exhibited a diverse spectrum of contextual uses in OldE. Firstly, to was used to mark a spatial direction (7a) with verbs that involved motion "cumen" (come), but it also occurred in non-spatial contexts $(7 \mathrm{~b})$ where it marked a chronological direction ("to æfenes" till evening) or in religious contexts (7c) where it marked a direction towards the divine ("gehwyrfp to" convert to) (examples cf. de Cuypere 27-28).

(7) a. ðæt he cumen to Galileum

"That they may come to Galilee" 
b. he afæste to æfenes

"he fasted till the evening"

c. manige Israhela bearna he gehwyrfb to heora Drihtne;

"many of the children of Israel he shall convert to their Lord"

Furthermore, de Cuypere (op. cit.) argues that to was used in OldE in the to-dative construction to refer to either a (i) location (8a) or (ii) person (8b) (example cf. de Cuypere 28).

(8) a. Hi ða gelaðodon hine to heora gest-huse

"Then they invited him to their guest house"

b. and sende his gewrit to bam wælhreowan casere "and sent his letter to the cruel emperor"

Worth mentioning are the abstract uses of to in Old English, which illustrate that its semantic uses went way beyond that of a Goal marker. To was used as an index of a place or a certain point in time (see $(9 a, b)$ below); it indicated "a condition to be attainted" or "an occasion to be attended" (9c-d) and last but not least to was used as a purpose, comparison and source marker (9e-g) (examples cf. de Cuypere 30-31).

(9) a. settan him hyrdas to

"set guards over him"

b. to midre nihte "at midnight"

c. Crist hi gebrohte to ecere reste

"Christ has brought her to eternal rest"

d. pæt he wolde hine sylfne syllan to deaðe "that he wanted to give himself to death"

e. pæt nan man ne sylle nan feoh to gafole "that no man not shall give no money as rent

"that no one shall give money as rente"

f. he worhte pa Adam to his anlicnysse.

"then he created Adam in his own likeness."

g. Swá ic ðé wéne to

as I you expect to

"as I expect of you"e

Interestingly, the to-dative was also used as a Recipient in OE, however rare; a few instances have been found with the following verbs: agiefan ("to 
give"), lettan ("leave", "let") and niman ("take", "receive") where a certain possessional transfer can be inferred. It was only starting with the Middle English period that the to- dative was often used with verbs of transfer of possession followed by a human recipient, in line with (de Cuypere op cit.)

(10) Eadward cyning \& pa hiwan in Wintanceastre lætað to Đænewulfe bisceope twentig hida lands

"King Edward and the household in Winchester leave to bishop Denewulf twenty hides of land

(de Cuypere 33-34)

What these examples indicate is that the to-dative construction can be found in Old English texts with verbs of caused motion and of communication. I have shown that the Recipient use of the to-dative was also present in OE texts, however in an "embryonic" state, as it was not used with transfer of possession verbs, but its meaning could have been inferred when used with such verbs as lettan ("leave", "let") niman ("take", "receive"), agiefan ("to give"). As already suggested, the to-construction was commonly used in OE with other ditransitive verbs such as verbs of communication (cweðan "to speak", sprecan "to say, utter", cleopian "to call" etc.) and verbs of caused motion (sendan "to send", bringan "to bring" etc.), which illustrates that during that period the construction was already existent.

In contrast, McFadden (2002) attests the presence of the to-dative construction starting with Middle English texts (1150-1250) which appeared simultaneously with the loss of the Dat-Acc case distinction. The to-dative had one underlying structure where the DO c-commanded the IO (2002: 17) and it was found in Middle English (1150-1250) texts with such verbs as give, grant, show, teach and tell, however its presence was very limited as compared to the double object construction. Later on, in between 1250-1350, the to-dative became a viable option as the Dat-Acc distinction had been lost.

\section{A DIACHRONIC PERSPECTIVE ON LA "AT/TO"}

Romanian has kept from old Latin the analytical marking of the Dative which is realized through the P la "at/to". As opposed to other Romance languages, the synthetic and analytical types of marking are used in present-day standard Romanian, following a set of morphological restrictions (when the first component of the DP cannot host the specific dative case-marker, the analytical 
marking is called for). From a diachronic perspective, the prepositional marking of the Dative dates back to the III and II B.C where the P $a d$, coming from old Latin, was used to assign the thematic role of Beneficiary within ditransitve structures; moreover, the $a d+$ Acc marking was used to mark both the IO and the adnominal dative by replacing the synthetic Dative.

$L a$ evolved from the Latin preposition $a d$; the $\mathrm{P} a$ was first used to mark a Dat-Gen relation. In the XVII century, the Latin $a$ was restricted to the marking of the Genitive, while la was used to mark the Dative, following Iorga (2013). Grammarians indicate that the IO Dative was frequently used in OldR as opposed to present-day language as many verbs required the dative marking, following their Slavic origin as in a crede "to believe", a judeca "to judge". Old texts exemplify the fact that there was a tendency to mark the prepositional Dative both with $a$ and $l a$, as illustrated in (11), until $l a$ became standardized, towards the end of the XVIII century.

(11) să o dăm $a$ oamini to give A people "to give to people"

(Gheție 152, quoted in Iorga 127)

In the same line of thought, Iorga (op. cit.) notices that, similar to present day standard Romanian, the prepositional Dative in Old Romanian (marked a/la) was used with components that lacked case-marking: quantifiers, indefinite pronouns and adjectives, possessive pronouns and adjectives as illustrated in (46ac).

(12) a. Nimea nu poate a doi domni sluji nobody no can A two lords serve

"Nobody can serve to two lords"

(Iorga 135)

b. Să-ş mărturisască la tot omul minunea şi mila de la Domnul sasubs he.DAT.CL confess.SUBJ.3SG LA every man wonder.the and mercy from God

"To confess to every man the wonder and mercy from God" (Iorga 135-136)

c. La ai noştri buni priiatini şi fraţi, domnie de Bistriţă, să să dě aciastă carte

LA our good friends and brothers kingship of Bistrita sasuBs give this book

"To our good friends and brothers, kingship of Bistrita, this book be given"

(Iorga 135-136) 
Similarly, the author notices that in Old Romanian, the prepositional marking of the Dative $(a / l a)$ was used even where the first component of the DP could host the specific dative case-marker as in the case of indefinite pronouns and adjectives (13a, b), demonstrative pronouns (13c), qualitative adjectives (13d) and rarely with reflexive, relative and negative pronouns.

(13) a. Frânge capetele pre pământ $a$ mulţi breaks heads.the on Earth A many "Breaks the heads on the Earth to many"

(Iorga 2013: 131)

b. Apoi vă dăm de ştire la toţi, ca domnilor noştri vecini credincioşi then CL.DAT.3PL give news LA everyone as gentleman our neighbours devoted

"Then we give the news to everyone, as our gentleman devoted neighbors"

(Iorga 137)

c. Strigă cinstitul bătrân acela ca la un viu la acel mort Shouts honest old man that as to a living LA that deceased "Shouts the honest man as to a living being at that deceased" (Iorga 137)

d. Scriem închinăciune şi sănătate la iubiţi şi dulci priiatini write prayer and health LA beloved and sweet friends "We write prayers and health to beloved and sweet friends" (Iorga 137)

In spite of the fact that structures with the $\mathrm{P} a$ marking a dative relation were frequently used in old Romanian, prepositional $a$ is still used in present day Romanian where it marks the dative assigned by grație "thanks to", mulțumită "thanks to", datorită "because of", conform "according to", contrar "contrary to" as the examples indicate:

(14) a. (datorită) a două rude because-of A two relatives.NOM=ACC

b. (contrar) a (ceea) ce văzusem contrary-to A what seen

It is worth mentioning that $16^{\text {th }}$ century texts indicate the presence of functional $l a$ as an analytical marking of the Genitive occurring with cardinal numbers, proper names and quantifiers, see (15a-c) below. 
(15) a. "numele la doi greci viteazi” (Pană Dindelegan 168) name.DEF LA two Greeks brave "the name of two brave Greeks"

b. "numele la Istoriile Râmului" (Costin 266)

name.DEF LA Histories Râmului "the names of the Histories of Râm"

c. "obiceiu la toți domnii" (Ureche 179) custom LA all lords "custom of all lords"

What this historical investigation indicates is that la, throughout its evolution from the Latin preposition $a d$, has served as both a Dative and Genitive marker. Old Romanian texts indicate a high frequency of $l a$ as a prepositional marking of the Dative, which led to its standardization as a Dative marker $\left(17^{\text {th }}\right.$ century). Moreover, la in $16^{\text {th }}-17^{\text {th }}$ century texts occurred following the same morphological constraints that are available in ModR, thus its use was similar. With the above evidence, I hypothesize that Romanian has managed to preserve the prepositional marking of the Dative in its present form due to: (i) its constraint (it is used with invariable constituents) and (b) its frequency of use, where the latter might have influenced the occurrence of the la-marking in present dialectal Romanian where it is not morphologically imposed. What is also interesting is that the role Romanian la stretches way beyond the marking of the Dative, in that it is used as a Genitive marker in present dialectal Romanian.

Romanian, similar to Spanish (Fabrgas 2007) exhibits two series of locative prepositions which assign Gen/Dat to their complement; these are (a) the IN series: înainte (forward, ahead), înapoi (back(ward)), înăuntru (inside), îndărăt (behind, back) afara/în afara (outside) and (b) the DE series: dinainte (forth, in front of), dinapoi (back, at the back of), dinăuntru (from inside), dindărăt (back, at the back of), din afară (from outside). The two sets exhibit complex syntactic and semantic properties; syntactically, if they are definite they assign Gen to their complement and if there is no definite article, the complement is realized as a Dative and cliticisation is called for (see 16a, b below). Semantically, following Svenonius (2004) these complex Ps receive an Axial Part interpretation: the P functions as an Axial Part, while the Gen object is the Ground; in other words, a Figure-Ground construction is being composed where the $\mathrm{P}$ projects a location with respect to the Gen object (16c).

(16) a. Fetița a sărit înaintea mea.

Girl.the has jumped in-front-the I.Gen

"The girl has jumped in front of me."

b. Mi-a sarit înainte o căprioară. 
I.Dat.cl-has jumped in front of me

"A deer has jumped in front of me".

c. Școala este înaintea bisericii.

School.the is ahead-of church.the.Gen

"The school is ahead of the church"

One can find instances, using Google, of the two series of locative prepositions that occur in structures where the Gen is marked by functional la; it is nevertheless clear that these occurrences belong to dialectal language. Firstly, if we look at the IN-series, one important aspect to mention is that present-day Romanian frequently exhibits occurrences where the Ps may select a Gen complement that is prepositionally marked by the functional la. In such cases, once the Gen is selected, the IN-series $\mathrm{P}$ will acquire the definite article (see (17ai) below).

(17) a. "dragostea înaintea la toate" love ahead AT everything "love ahead of everything"

b. "sunt impotriva la toți candidații" are against $\mathrm{AT}$ all candidates "(they) are against all candidates"

c. "tratament la pereți împotriva la umezeală" treatment AT walls against AT damp "wall treatment against damp"

d. "despre Mașini împotriva la zombi apasă aici” about cars against AT zombie click here "about cars against Zombies, click here"

e. "să poată da și îndărătul la cine trebuie" can give back AT whomever needs "to be able to give back to whomever needs"

f. "mâncare adevarată împotriva la mâncare prăjită" food real against AT food deep-fried "real food against deep-fried food"

g. parlamentarii PNL nu vor vota împotriva la imunităţi MPs.the PNL will not vote against AT indemnities "the PNL MPs won't vote against indemnities"

h. "Sucul din Roșii împotriva la Roșii Proaspete" juice out of tomato against AT tomato fresh "tomato juice against fresh tomatoes" 
One observation is in order here. In Romanian, the alternation of nominal constituents marked with inflectional Gen with those headed by $l a$ is a matter of stylistic difference, where the inflectional BGen belongs to standard Romanian and the la-marking belongs to dialectal language. Thus the idea according to which Romanian seems to have an intermediate position on the synthetic-analytic scale can be further extended to the Gen, where the la-genitive seems to have become a frequent option among non-educated speakers of Romanian, with a high degree of frequency.

Moreover, complex prepositions from the $I N$-series that are based on nouns that denote body/object parts (în fața (in front of), in spatele (in the back of) etc.) are found in structures where the genitive is marked by the functional la "at/to". As noted above their interpretation is twofold, they denote a body/object- part and they may also denote a particular space (Ground) which is projected from the object part. In other words dialectal Romanian exhibits Ps functioning as Axial Parts with overt complements marked by the P la "at/to" (see (18a-c) below):

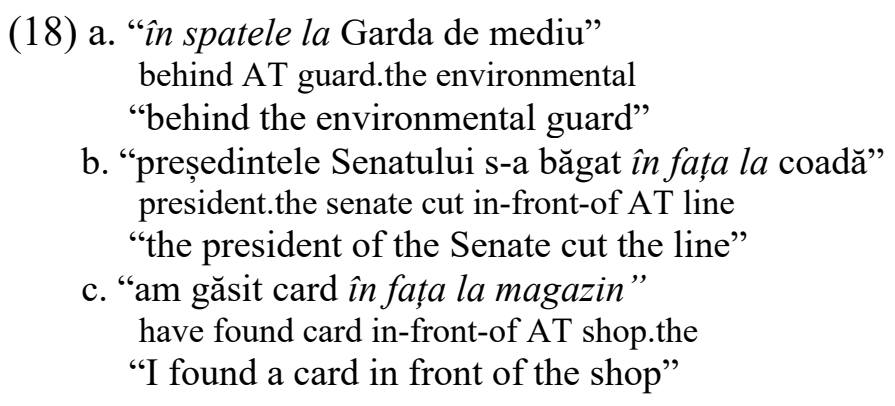

As compared to $\mathrm{P}$ belonging to the IN-series which are found in structures where the genitive is marked by the functional la "at/to", few Ps from the DEseries exhibit the same pattern in non-standard Romanian. Similarly, when Ps from the IN-series select a Gen complement they acquire the definite article.

(19) a. "manevra cu dindărătul la pace" trick.the with DE+behind.the AT peace "the trick behind peace"

These complex Ps exhibit one important property- they combine with the definite article; thus, they are gender/number/case- marked (consider (20a-c) below) which point towards the fact that these Ps are nouns, as it has already been suggested in the literature (Botwinink (2004), Terzi (2010))

(20) a. dindărăt(u)I [M]

b. înainte+a [F] 


\section{c. în afara $[\mathrm{F}]$}

Like other Ps assigning the Gen to their complement, din cauza ("because of') can occur in non-standard Romanian with the la-genitive (see 21(a,b) below).

(21) a. "din cauza la ploaie s-a inundat pasajul subteran" because of AT rain.the CL.REFL.PASS=(it) has flooded tunnel underground

"because of the rain the underground tunnel was flooded"

b. "din cauza la vremea urâtă" because of AT weather.the bad "because of the bad weather"

What the above examples illustrate is that functional la has become a marker of the Gen in dialectal Romanian in contexts with complex locative prepositions. Prepositions from the IN-series select in non-standard Romanian Gen complements that are prepositionally marked by the functional la, even if the complement does not lack case inflection as in dragostea innaintea la toate "love ahead of everything" or in spatele la Garda de mediu "behind the environmental guard" where in spatele functions as an Axial Part. Ps from the DE-series exhibit the same pattern but the frequency is lower (manevra cu dindărătul la pace "the trick behind peace").

\section{CONCLUSIONS}

The examination has brought to light the presence of the to-dative construction in OldE with certain classes of ditransitive verbs such as verbs of communication (e.g. cweðan "to say") or verbs of caused motion (e.g. sendan "to send").

$L a$, throughout its evolution from the Latin preposition $a d$, has served as both a Dative and a Genitive marker. OldR texts indicate a high frequency of $l a$ as a prepositional marking of the Dat, which led to its standardization as a Dative marker, in the $17^{\text {th }}$ century. Interestingly, in ModR la stretches beyond the marking of the Dat and it is used as a Genitive marker in present-day dialectal Romanian.

\section{Corpus}

Costin - Miron Costin. Opere alese, ed. by P.P. Panaitescu, Bucharest: Editura Tineretului: 1958. 
Ureche - Grigore Ureche. Letopisețul țării Moldovei, ed. by P.P. Panaitescu, 1955, București: ESPLA.

\section{Works Cited}

Botwinik-Rotem, I. 2004. The Category P. Features, Projections, Interpretation. Ph.D. dissertation, University of Tel-Aviv

Cornilescu, A. 2020. "Ditransitive constructions with differentially marked objects in Romanian". In Anna Pineda\& Jaume Mateu (eds.), Dative constructions in Romance and beyond, Berlin: Language Science Press. 117-142.

De Cuypere, L. 2014. "The Old English to-dative construction." English Language and Linguistics 19(1), 1-26.

Iorga, Mihail, A. 2013. O tipologie a Dativului românesc. Dativul în grupul verbal. Ph.D. thesis, University of Bucharest.

McFadden, Thomas. 2002. "The rise of the to-dative in Middle English." In David W. Lightfoot. (ed.), Syntactic effects of morphological change. Oxford: Oxford University Press.107-123.

Pană-Dindelegan. 2013. "Flexiunea cazuală: între analitic și sintetic. Cardinale și cuantificatori în Româna veche.” In Limba Română, 3. 159-173

Rappaport Hovav, M. \& B. Levin. 2008. "The English dative alternation: The case for verb sensitivity." Journal of Linguistics 44. 129-167

Terzi, A. 2010. "On null spatial Ps and their arguments", Catalan Journal of Linguistics 9, 167-187.

\section{BIONOTE}

Tania ZAMFIR, $\mathrm{PhD}$ is an external collaborator at Transilvania University of Braşov, in the department of Theoretical and Applied Linguistics. She has a $\mathrm{PhD}$ in Linguistics from University of Bucharest with the title Ditransitive structures: the English $P$ "to" and the Romanian $P$ "la”, under the supervision of Prof. Emeritus Alexandra Cornilescu. She is interested in syntax, semantics and generative grammar and I am currently working on a project with the Romanian Dative.

Email: tania.zamfir@yahoo.com 